\title{
TRWALE CZYNNIKI W ROSYJSKIEJ POLITYCE ZAGRANICZNEJ
}

\section{Persistent Factors in Russian Foreign Policy}

The article presents the concept of persistent factors in the foreign policy of Alfred Rieber and places it in the context of disputes about determinism in geopolitics. At the same time, using the example of Russia, it refers to the discussions that have been conducted by Polish Sovietologists since the 1920s. The theory of persistent factors makes it possible to reconcile geopolitical and civilizational trends emphasising the importance of long duration'. It is also an example of empirical investigation of evidence and a contribution to comparative research.

Keywords: foreign policy, geopolitics, persistent factors, determinism.

\section{WPROWADZENIE}

W 2014 roku świat został zaskoczony kryzysem na wschodniej Ukrainie. Rosyjskie wojska zajęły Półwysep Krymski, a na terenie ukraińskich okręgów ługańskiego i donieckiego Rosja zaczęła prowadzić wojnę hybrydową. Nagła eskalacja konfliktu, bezpośrednie oraz pośrednie zaangażowanie militarne Rosji spowodowały odnowienie się dyskusji na temat roli tego kraju w światowym systemie bezpieczeństwa. Wraz $z$ tą dyskusją powrócił temat przynależności Rosji do świata zachodniego, a co za tym idzie jej „normalności”. Próby zrozumienia Rosji przez zachodnich komentatorów i naukowców sa w dużej mierze obciążone dotychczasowym dyskursem silnie zakorzenionym w geopolitycznym paradygmacie. Ekspansjonizm oraz wy- 
jątkowość miałyby być dwoma głównymi czynnikami warunkującymi zachowanie Rosji na arenie międzynarodowej. Ekspansywność zwykło się uzasadniać brakiem fizycznych barier azjatyckiej tundry i stepu oraz potrzeba posiadania portów na niezamarzających morzach.

Te tłumaczenia choć silnie umocowane w literaturze naukowej nie są wystarczające. Wydaje się, że geopolityczny paradygmat prowadzenia polityki nie jest $\mathrm{w}$ stanie przynieść pełnej odpowiedzi na pytanie o źródła zachowania Rosji.

Artykuł ten ma na celu zmianę optyki badawczej i rozszerzenie geopolitycznego paradygmatu, który obciąża dyskurs o Rosji. Jeden z ważniejszych sowietologów i historyków zajmujących się Rosją Alfred J. Rieber zaproponował szersza perspektywę badawcza skupiajaca się na trwałych czynnikach w polityce. Trwałe czynniki oparte sa na przekonaniu o ciagłości w rosyjskiej polityce zagranicznej, jednakże odrzucaja wszelkie teorie o determinizmie historycznym i politycznym ${ }^{1}$. W ten sposób Rieber rozszerza geopolityczny paradygmat o Braudelowską teorię długiego trwania.

O tym, jak potrzebna i wartościowa jest to perspektywa, można przekonać się śledząc dyskusję o najnowszej publikacji Jacka Bartosiaka Rzeczpospolita między lądem a morzem. O wojnie $i$ pokoju. Ta liczaca ponad osiemset stron książka stanowi jak dotychczas najbardziej ambitne i kompleksowe przeniesienie geopolityki na grunt polski, przynajmniej geograficznie. Część tej publikacji jest poświęcona Rosji i jej polityce zagranicznej.

Główna krytyka jaka spotkała Bartosiaka czy to ze strony Michała Lubiny, czy Karola Kaźmierczaka dotyczy przede wszystkim tego, że traktuje on przestrzeń geograficzna jako podstawowy czynnik determinujacy politykę podmiotów w niej funkcjonujących. Od tej przypadłości nie jest także wolna Rosja. Kaźmierczak zaś podkreśla, że Bartosiak wykorzystuje geopolitykę do tworzenia zbyt prostych analogii i dokonuje nieuprawnionej ekstrapolacji trendu. W języku Bartosiaka polityka jest zakładnikiem „odwiecznej, naturalnej dynamiki”. To geografia warunkuje zachowanie Rosji, a nie np. struktura stosunków międzynarodowych, psychologia elit rządzących, czy patrzac szerzej - struktury kulturowe i cywilizacyjne. Jest to według Kaźmierczaka zwyczajny redukcjonizm. Uważa on, że nie ma ciagłości we współczesnej Rosji z czasami sowieckimi i carskim. Brak jest

1 A. Rieber, How persitent are persistent factors? w: Russian Foreign Policy in the XXI Century and the Shadow of the Past, ed. R. Legvold, New York 2007, s. 205. 
także uniwersalistycznej idei (słowianofilstwo czy dominacja komunizmu). Rosję spaja tylko nacjonalizm (językowo-etniczny) ${ }^{2}$. Kaźmierczak zatem wskazuje na inne niż geograficzne determinanty prowadzenia polityki zagranicznej. Być może propozycja stawiana przez Riebera pozwoli uciec od pułapki determinizmu zarówno definiowanej geograficznie, jak i kulturowo. Rieber postuluje nie perspektywę od góry do dołu, ale $z$ dołu do góry - poprzez holistyczna analizę konkretnych działań w polityce zagranicznej opartej na szerszym kontekście geograficznym, politycznym, kulturowym czy cywilizacyjnym ${ }^{3}$.

Propozycja Riebera wpisuje się także bardzo dobrze w obecna (przełom roku 2018 i 2019) dyskusję na temat roli geopolityki, jaka przetacza się przez polski dyskurs publiczny i ekspercki. Jednakże, żeby móc przyjąc optykę badawcza Riebera, należy najpierw postawić pytanie czy możliwe jest mówienie o ciagłości w przypadku Rosji, która przeszła przez XX wiek w burzliwy sposób i została naznaczona rewolucyjnymi przemianami? Upadek imperium carów, rozwój Związku Sowieckiego i jego późniejszy rozpad, to wszystko przełomowe wydarzenia, których doniosłość i znaczenie mogły przerwać ciągłość. Zwłaszcza biorąc pod uwagę ideologiczne podstawy rewolucji komunistycznej, która chciała walczyć ze starym porządkiem i stworzyć nowy, swój własny. Czy można zatem mówić o ciagłości?

\section{ROSJA I CIĄGŁOŚĆ}

Aby odpowiedzieć na pytanie o istnienie ciąłości w rosyjskiej polityce zagranicznej, najlepszym rozwiązaniem wydaje się zaczerpnięcie $z$ bogatego dorobku argumentów powstałych w długiej dyskusji toczonej przez przeciwników i zwolenników tezy o ciagłości. Warto tutaj wspomnieć o dorobku polskiej szkoły sowietologicznej, która w prekursorski sposób opisała fenomen Zwiazku Sowieckiego i czyniła to na goraco jeszcze w latach dwudziestych i trzydziestych. Należy wymienić tutaj takie postaci, jak Wiktor Sukiennicki, Stanisław Swianiewicz, Jan Kucharzewski, Marian Zdziechowski, Bogumił Jasinowski, Konstanty Grzybowski i inne ${ }^{4}$.

2 K. Kaźmierczak, Porażka Bartosiaka, https://kresy.pl/publicystyka/porazka-bartosiaka/ [dostęp: 26 lutego 2019].

Dyskusja toczy się przede wszystkim wokół publikacji Jacka Bartosiaka i Leszka Sykulskiego.

4 M. Kornat, Poczatki sowietologii $i$ studiów nad systemami totalitarnymi $w$ Polsce (1918-1939), Kraków 2003. 
Swianiewicz argumentował, że niektóre rozwiąania gospodarcze wprowadzane w ZSRS wynikaja bezpośrednio z geograficznego ukształtowania tego kraju i jego niezmierzonych przestrzeni. Wykazywał zatem elementy myślenia geopolitycznego ${ }^{5}$. Jan Kucharzewski $z$ kolei upatrywał przyczyn polityki sowieckiej w tzw. długim trwaniu - w procesach społecznych i kulturowych rosyjskiej ludności. Stawia on tezę o ciagłości pomiędzy czasami przedrewolucyjnymi i porewolucyjnymi. Ciagłość ta miała zostać zachowana poprzez mentalność elit państwowych, jak i szerokiej populacji ${ }^{6}$. Ten pogląd krytykował Andrzej Walicki - widząc znaczącą różnicę jakościową (umasowienie zniewolenia), która nie miała miejsca w Rosji carskiej ${ }^{7}$. Z kolei Marian Zdziechowski kształt, jaki przyjał ZSRS, widział w lokalnej, rosyjskiej specyfice interpretowania marksizmu. Decydujacy był zatem aspekt pewnej ciagłości kulturowej ${ }^{8}$. Podobnie uważał Bogumił Jasinowski, jednak dla niego wpływ historii rosyjskiej na kształt ZSRS nie nosił znamion determinizmu kulturowego. Jak będzie widać poniżej, podstawowe podziały dotyczace historycznej interpretacji tego, czym był ZSRS, zaczęły się już w momencie jego powstania. Podwaliny pod dyskusję położyła właśnie polska szkoła sowietologiczna.

Dopiero $\mathrm{w}$ latach czterdziestych XX wieku wraz $\mathrm{z}$ militarnymi sukcesami ZSRS na Zachodzie zaczęto dyskutować o źródłach takiej, a nie innej polityki sowieckiego imperium. Rosyjski socjolog Mikołaj Timaszew w 1953 roku był jednym $z$ badaczy próbujących rozwikłać rosyjski problem. Pochodził on ze starego rosyjskiego, arystokratycznego rodu i był bardzo krytyczny w stosunku do komunizmu, który, jak uważał, rujnował jego ojczyznę. Jednocześnie Timaszew był przekonany, że komunizm stanowi nowa jakość na światowej arenie i odpowiada za ekspansjonistyczną politykę ZSRS. Uważał on, że wcześniejsza ekspansja Rosji nie różniła się od praktyk innych państw. Stany Zjednoczone poszerzały swoja frontier do Pacyfiku, Holandia, Hiszpania, Francja i Anglia budowały swoje imperia kolonialne. W tym zestawieniu rosyjska ekspansja nie była niczym nadzwyczajnym, skoro taki był trend epoki. Timaszew uznaje, że rosyjska ekspansywność miała swoje granice warunkowane głównie geogra-

5 S. Swianiewicz, Rzut oka na zasadnicze problemy sowieckiej polityki gospodarcze, Rocznik Instytutu Naukowo-Badawczego Europy Wschodniej w Wilnie, t. 2, 1934, s. 5.

6 J. Kucharzewski, Od białego caratu do czerwonego, t. 1, Warszawa 1998, s. 49.

A. Walicki. Zniewolony umyst po latach, Warszawa 1993, s. 113. s. 313 .

M. Zdziechowski, Podstawy kultury nowoczesnej; M. Kornat, Poczatki sowietologii ..., 
ficznymi czynnikami. Natomiast komunistyczny Związek Sowiecki wprowadził nowa jakość. Ekspansja nie była oparta na geopolitycznych podstawach, ale była warunkowana ideologicznie. Ostatecznie rewolucja komunistyczna, a zatem i ZSRS miał objąć całą kulę ziemską. Przesłanie marksizmu-leninizmu jest uniwersalistyczne, chociaż trudno je pogodzić ze stalinowska doktryna komunizmu w jednym państwie. Timaszew argumentował, że pomysł Stalina miał być jedynie tymczasowy. W teorii kapitalistyczne państwa miały wywoływać wojny między soba, a komunizm powinien wykorzystywać te konflikty, by poszerzyć swój stan posiadania. Brak uniwersalizmu w idei ekspansji przedrewolucyjnej Rosji opartej o autokrację, prawosławie i ludowość to koronny argument Timaszewa przeciwko tezie o ciągłości rosyjskiego ekspansjonizmu9. Podobne poglądy wyrażał autor monumentalnego dzieła Archipelag Gułag. Według Aleksandra Sołżenicyna nie można porównywać opresyjności i agresywności imperium Romanowów z Zwiazkiem Sowieckim. Powtarza on tezę Timaszewa o ideologicznej zmianie jakościowej (i ilościowej) w ZSRS. Jednakże pozostaje on bardziej krytyczny wobec czasów przedrewolucyjnych ${ }^{10}$.

W tej dyskusji po przeciwnej stronie barykady stoi polski badacz Oskar Halecki. Niejako antycypujacc artykuł Timaszewa w 1952 przedstawił tezę o ciagłości rosyjskiego imperializmu, którego jest Związek Sowiecki. Halecki argumentuje, że tym co odróżnia Rosję od zachodnioeuropejskich państw to historia ciagłej i nieprzerwanej ekspansji. Następnie przedstawia krok po kroku długa listę rosyjskich i sowieckich podbojów. Czyni to w sposób do pewnego stopnia anachroniczny, np. nazywajac wojenne i dyplomatyczne działania Iwana III pierwsza w historii zimna wojną. Pisząc swoją historię $z$ polskiego (czy jakby chciał to ując, środkowoeuropejskiego) punktu widzenia, Halecki wymienia ideologiczne podstawy rosyjskiej ekspansji. Rosja miała traktować ziemie Wielkiego Księstwa Litewskiego jako ruskie, czyli nie tylko etnicznie rosyjskie, ale także historycznie przynależne do Rosji. Idea ta miała później ewoluować w agresywny panslawizm. Argumenty Haleckiego częściowo obalaja ustalenia Timaszewa o braku uniwersalistycznych idei w przedrewolucyjnej Rosji. Car rościł sobie prawo do rządzenia wszystkimi ludami prawosławnymi, wszystkimi ludami rusińskimi, a w końcu i wszystki-

9 N. Timaszew, Russian imperialism or Soviet aggresion? w: Soviet Imperialism. It's Origins and Tactist, ed. W. Gurian, Notre Dame 1953, s. 35-38.

${ }^{10}$ A. Solżenicyn, The Russian Question at the End of the Twentieth Century: Toward the End of the Twentieth Century, New York 1995. 
mi Słowianami. Ekspansja miała również dotyczyć całych Bałkanów, które nie były zamieszkane li tylko przez ludy i narody słowiańskie i prawosławne.

Podobne argumenty do Haleckiego wysuną również inny badacz polskiego pochodzenia Richard Pipes ${ }^{11}$. Ten doradca amerykańskiego prezydenta Georga Busha Seniora jako podstawę swoich rozważań przyjął właśnie ciagłość, jaka wystapiła w przedrewolucyjnym reżimie oraz $\mathrm{w}$ trakcie panowania reżimu komunistycznego. $Z \mathrm{a}$ te poglądy został skrytykowany przez wspomnianego wyżej Sołżenicyna, który zarzucał Pipesowi tworzenie polskiej wersji rosyjskiej historii. Pipes bronił się, twierdząc, że Sołżenicyn prezentuje skrajnie nacjonalistyczne podejście do rosyjskiej przeszłości ${ }^{12}$.

Powyższa debata, mimo że prowadzona na akademickim poziomie, pokazuje głębokie zaangażowanie dyskutantów i ich uwikłanie $\mathrm{w}$ temat sporu. Jest to szczególnie widoczne w tekstach Haleckiego i Timaszewa. Ich analizy nie sa dokonywane sine ira et studio, lecz na siłę próbują naciagnać fakty do swoich teorii. Pomimo problemów z obiektywizmem naukowym, należy przyjąć, że teza o ciagłości rosyjskiego/sowieckiego imperializmu jest bliższa prawdzie. Argument Timaszewa o tym, że przedrewolucyjny rosyjski imperializm różni się od sowieckiego tylko dlatego, że taki był duch czasów i inne państwa również kolonizowały wtedy świat nie jest odpowiednia podstawą do formułowania takiej konkluzji. Nie wiąże się on wcale $z$ zagadnieniem ciagłości i stanowi jedynie usprawiedliwienie rosyjskiego imperializmu, nie podważa zaś tezy o ciagłości. Natomiast Halecki, pomimo że przyjmuje tylko środkowoeuropejska perspektywę w ocenie rosyjskiej ekspansji i wielu anachronizmów, pokazuje liczne paralele pomiędzy przeszłością i teraźniejszościa. Nie zgłębia jednak tematu wystarczająco. Dopiero Richard Pipes, dokonując dogłębnej analizy, zaczyna doszukiwać się korzeni Związku Sowieckiego już w XVI wieku w Księstwie Moskiewskim. Argumentuje, że autokratyczne państwo moskiewskie rozwijało się zupełnie inaczej niż Europa. U podstaw tej odmienności miało leżeć podejście do własności prywatnej. To władca - car był samodzierżawcą i jedynym właścicielem wszystkiego w swym państwie. Taki model własności miał być dziedzictwem mongolskiego panowania.

11 R. Pipes, Rosja carów, Warszawa 2007; idem, Rosja bolszewików, Warszawa 2007.

12 N.D. Smith, A Cold Warrior at Peace, „Wall Street Journal” http://www.wsj.com/articles/SB10001424053111903596904576516652848445180 [dostęp: 2 maja 2016]. 
Teza Pipesa warta jest głębszej analizy, ponieważ rodzi poważne implikacje. Po pierwsze skoro Rosja stanowi inny twór cywilizacyjny, czy można ja porównywać, tak jak czyni to Timaszew, $z$ kolonialnymi mocarstwami Europy Zachodniej? Czy ta odmienność nie tworzy zupełnie innych paradygmatów prowadzenia polityki i odmiennej siatki pojęciowej, która różniłaby się od tej używanej w Europie? Najważniejszym pytaniem jest jednak, czy teza Pipesa jest uprawniona?

\section{CYWILIZACYJNE PODSTAWY ROSYJSKIEJ ODMIENNOŚCI}

Samuel Huntington w Zderzeniu cywilizacji wyszczególnił w swojej analizie osiem głównych cywilizacji. Co ważne, w tych rozważaniach od cywilizacji zachodniej oddzielił inna, sąsiadująca $z$ nia cywilizację prawosławna. W skład cywilizacji prawosławnej wchodza państwa bałkańskie (bez Chorwacji i Słowenii) oraz większość byłych terytoriów ZSRR, a głównym ośrodkiem tej cywilizacji jest Rosja. Jakie zatem sa podstawy rozróżnienia cywilizacji prawosławnej od zachodniej? Cywilizacja zachodnia dla Huntingtona wyróżnia się przede wszystkim dziedzictwem starożytności klasycznej, tzn. stworzona wtedy filozofia, systemem prawnym, literatura itd., a za najważniejszą spuścizna antyku uznał on prawo rzymskie. Stosowanie tego prawa doprowadziło do brzemiennego w skutki rozdzielenia sfery sacrum i profanum (co nie nastapiło w żadnej innej cywilizacji wymienianej przez Huntingtona). Implikacja tego podziało jest rozdział władzy doczesnej od władzy duchowej i co za tym idzie rządy prawa. Kolejnym najważniejszym wyróżnikiem jest przynależność do „chrześcijaństwa zachodniego”, tzn. katolicyzmu i różnych odmian protestantyzmu. To właśnie wyróżnik religijny wydaje się najważniejszy w rozumowaniu Huntingtona.

Cywilizacja prawosławna od cywilizacji rzymskiej różni się zupełnie innymi korzeniami i pochodzeniem. O odrębności religijnej maja świadczyć bizantyńskie wpływy, a o odmienności politycznej wpływy dziedzictwa Złotej Ordy. Dziedzictwo to charakteryzuje się antydemokratycznym biurokratyzmem oraz emocjonalna antyzachodniością ${ }^{13}$.

Trudno przyjąć podstawę religijną jako najważniejszy wyróżnik cywilizacyjny. Dogmatycznie nie istnieje wiele różnic pomiędzy katolicyzmem, zaliczanym przez Huntingtona do cywilizacji zachodniej, a prawosławiem. Dopiero jeśli przyjrzeć się relacji instytucji religij-

${ }^{13}$ Cyt za: R. Krawczyk, Podstawy cywilizacji europejskiej, Warszawa 2006, s. 130. 
nych $z$ władzą świecka, można dostrzec znaczące różnice, zwłaszcza podległość cerkwi władzy cywilnej, która to relacja nie ma odpowiednika w chrześcijaństwie zachodnim.

Najważniejszym jednak argumentem przemawiającym za cywilizacyjna odmiennością Rosji od świata zachodniego, który wymienia Huntington (choć dla niego samego nie jest on najbardziej znaczacy), to wspomniane dziedzictwo Złotej Ordy. Argument o mongolskich wpływach na cywilizacyjny kształt Rosji był podniesiony także przez Richarda Pipesa, dlatego warto mu się bliżej przyjrzeć.

Jeśli przyjąć perspektywę religijna, oznaczałoby to, że Rosja jest spadkobierca antyku w stopniu równym Europie. Nieprzypadkowo to w Rosji powstała idea Trzeciego Rzymu. Czy wpływ dziedzictwa antyku nie wyklucza się $z$ typowo azjatyckim dziedzictwem Złotej Ordy?

Odpowiedź na to pytanie przynosi Rafał Krawczyk, badacz podstaw cywilizacji europejskiej. Twierdzi on, że warunki, w jakich powstawała i rozwijała się Rosja sa całkowicie odmienne od tych, które tworzyły śródziemnomorska cywilizację antyku. Fakt przyjęcia chrześcijaństwa $z$ Bizancjum nie jest gwarantem cywilizacyjnej ciągłości. Co więcej, tworzy zupełnie mylne przeświadczenie o europejskości rosyjskiej cywilizacji. W istocie bowiem ciąłość pomiędzy Bizancjum a Rosja, pomiędzy drugim a trzecim Rzymem miała wymiar jedynie symboliczny i powierzchowny, i nie mogła doprowadzić do utworzenia trwałych cywilizacyjnych podwalin. Utworzenie Państwa Moskiewskiego w znacznym oddaleniu od basenu Morza Śródziemnego doprowadziło do utworzenia odmiennego rodzaju cywilizacji prawosławnej ${ }^{14}$. Fizyczna odległość od Konstantynopola i Rzymu przyczyniła się do peryferyjności i izolacji powstającego zalążka przyszłej Rosji. Renesans idei antycznych o fundamentalnym znaczeniu dla cywilizacji europejskiej, jej tożsamości i rozwoju nie miał w Rosji w ogóle miejsca. Co więcej, nawet język, który sam w sobie jest nośnikiem idei, jest inny w rosyjskim obrzadku prawosławnym. Bizancjum posługiwało się greka, natomiast podstawą nabożeństwa rosyjskiego jest staro-cerkiewno-słowiański.

Poza chrześcijaństwem odziedziczonym po antyku Europa posiada również świecki łącznik ze swoimi śródziemnomorskimi przodkami. Jest to prawo rzymskie, podstawa większości europejskich systemów prawnych. Pierwszym, najważniejszym jego przejawem jest stosunek do własności i podmiotowość każdej jednostki. Drugim

14 Ibidem, s. 300. 
jest obecność prawa rzymskiego w miastach. Prawo funkcjonujące w rzymskich municypiach odżyło we włoskich miastach handlowych, a stamtąd rozeszło się po całej Europie. Do Polski trafiło w postaci tzw. prawa magdeburskiego zwanego też prawem niemieckim. Najdalej wysuniętym miastem na wschód, które funkcjonowało w oparciu o prawo niemieckie, był Kijów. Rola miast jest o tyle ważna, że nie tylko stanowią one lącznik $\mathrm{z}$ antykiem, ale również to $\mathrm{w}$ nich zaczał tworzyć się nowoczesny system gospodarczy nazywany kapitalizmem. Tutaj daje o sobie znać wspomniana peryferyjność Rosji, która nie przechodziła przez te procesy, a jedynie się do nich dostosowywała.

Jak widać oba najważniejsze łączniki $z$ cywilizacją śródziemnomorska, podstawa przyszłej Europy, w Rosji albo nie występują wcale, tak jak w przypadku obecności i oddziaływania prawa rzymskiego, lub łacznik ten jest ograniczony lub wypaczony, jak w przypadku rosyjskiego prawosławia. Źródeł podstaw cywilizacyjnych Rosji nie należy zatem szukać w Europie, ale rozważyć mongolskie wpływy Złotej Ordy.

Poczatki państwa rosyjskiego sięgaja roku 1253, kiedy to w stolicy mongolskiego imperium Karakorum podjęto decyzję o podboju znanego świata. Liczne armie konnych nomadów wyruszyły w każdym kierunku świata, także w stronę Rusi. Mongołowie stanowili zupełnie inną cywilizację od tych, które były wspomniane powyżej. Zarówno Rzym jak i Bizancjum to twory składające się $z$ osiadłej ludności trudniącej się rolnictwem i zamieszkującej miasta. Mongołowie zaś to lud koczowniczy. Powstałe na peryferiach mongolskiego imperium Państwo Moskiewskie a później Rosja byłaby w tym wypadku jedynym na świecie postkoczowniczym państwem i „żywym echem historycznego zderzenia cywilizacji nomadów $z$ cywilizacją ludów osiadłych"15. Moskwa podbita przez mongolskich najeźdźców stała się częścią imperium, by później na jego gruzach zbudować własne. Rytuały i sposób sprawowania władzy zostały przejęte od mongolskiego chana, a nie od basileusa $z$ Konstantynopola.

Ważna cywilizacyjną odmiennością nomadów jest inne podejście do własności niż to występujące u ludów osiadłych. W rolniczej społeczności Rzymian potrzebne było prawo by sankcjonować posiadanie własności oraz regulować jej obrót. W społecznościach koczow-

15 Rafał Krawczyk wysuwa nawet tezę, że jedynym prawdziwym zderzeniem cywilizacji jest starcie pomiędzy osiadłymi ludami rolniczymi a ludami koczowniczymi. Ibidem, s. 304. 
niczych nic takiego nie było nigdy potrzebne. Ziemia dla nomadów nie przedstawia żadnej wartości. Wypasa się na niej swoje stado, aż do wyjałowienia i następnie przenosi w inne miejsce. Zarówno zwierzęta jak i ludzie sa częścią takiego ruchomego stada, a właścicielem tego stada jest wódz, chan ${ }^{16}$. Stąd wywodzi się idea cara samodzierżawcy, właściciela wszystkiego czym włada, z ziemia i poddanymi włącznie. Co więcej, cała społeczność nomadów stanowi jednocześnie ruchoma armię, a organizacja państwa podporządkowana jest jedynie celom wojennym. Państwo nomadów to państwo ruchomego obozu wojskowego.

Taki system zarządzania społeczeństwem funkcjonował również w carskiej Rosji. Poza warunkami geograficznymi to właśnie taka konstrukcja społeczno-gospodarcza umożliwiała tak szybką ekspansję. Car zazwyczaj nie pobierał danin pieniężnych, które stymulowałyby rozwój rynku i kapitału. Zamiast tego wszystkie daniny publiczne podporządkowane były potrzebom militarnym i najczęściej były uiszczane w naturze. W ten sposób Rosja mogła, nie ponosząc dużych kosztów, korzystać z ludzkich zasobów do celów militarnych na niemożliwa do osiagnięcia w Europie skalę. Paralele ze Związkiem Sowieckim, rewolucyjną gospodarką wojenną oraz przebiegiem tzw. Wielkiej Wojny Ojczyźnianej nasuwają się same. Również Rosja Putina wykorzystuje zyski ze sprzedaży surowców naturalnych w dużej mierze na modernizację i utrzymanie armii ${ }^{17}$.

Kolejna pozostałością wpływów mongolskich w Rosji jest kształt rosyjskiego prawosławia. Chan zwolnił cerkiew od danin i podatków w zamian za całkowite polityczne podporzadkowanie. Poddanie się cerkwi chanowi mogolskiemu spowodowało zmiany w organizacyjnym kształcie tego kościoła. Większość kościołów prawosławnych funkcjonuje na zasadzie autokefalii, tj. niezależności lokalnych kościołów. Jednakże rosyjska cerkiew prawosławna rości sobie prawa do bycia jedynym ośrodkiem centralnym prawosławia. Widać to w szczególności w sile sprzeciwu wobec prób usamodzielnienia się cerkwi ukraińskiej i białoruskiej. Historyk i badacz Rosji oraz narodu rosyjskiego, Michaił Heller wskazuje na silnie antyzachodni kształt rosyjskiej cerkwi prawosławnej oraz wrogość wobec katolicyzmu i Za-

16 To właśnie $z$ języka mongolskiego pochodzą liczne słowa w j. rosyjskim, które dotyczą organizacji państwa: np. dziengi (pieniądze) czy czinownik (urzędnik).

17 Rosja wydała w 2015 roku ponad 4 proc. swojego PKB na utrzymanie armii. To proporcjonalnie więcej niż USA, które wydają lekko ponad 3 proc. Oczywiście w liczbach bezwzględnych to USA wydają więcej. 
chodu. Antyzachodni kształt cerkwii moskiewskiej scala kraj i społeczeństwo. Heller idzie jednak dalej i uznaje antyzachodniość jako istotna cechę rosyjskości jak takiej, nie ograniczając się tylko do sfery religijnej ${ }^{18}$.

Podejmowane wielokrotnie próby modernizacji Rosji na modłę europejska i zachodnią doprowadziły do ciekawej sytuacji. Oto cywilizacja, której jednym $z$ podstawowych elementów jest antyzachodniość próbuje stać się częścią tego znienawidzonego Zachodu (lub go przewyższyć, jak w przypadku ZSRS). Próby reformowania państwa przez Iwana Groźnego, Piotra I, Katarzynę II, Aleksandra I, Piotra Stołypina czy Michaiła Gorbaczowa miały charakter powierzchowny i zawsze spotykały się $z$ silna reakcja przeciwników modernizacji na zachodnią modłę. Większość $z$ podejmowanych prób miała charakter odgórnie i państwowo wprowadzonej zmiany pod przymusem. Te działania europeizacyjne pozostawiły bardzo znaczący ślad na kształcie rosyjskiej cywilizacji. Nadały jej zewnętrznemu obrazowy rysy europejskie. Być może to właśnie $z$ tego faktu wynika problem ze zrozumieniem Rosji przez Europejczyków. Posiadając europejską fasadę, Rosja komunikuje się $z$ Zachodem $\mathrm{w}$ podobnym języku, jednak znaczenie słów jest zupełnie inne.

Różnice $\mathrm{w}$ mentalności dobrze odzwierciedlają różnice $\mathrm{w}$ rozumieniu znaczeń tych samych pojęć. Jednym $z$ przykładów może być sowieckie rozumienie pokoju. Apelując o pokój na świecie, Związek Sowiecki rozumiał światowa dominację proletariatu, która miała zakończyć wszystkie wojny. Innym przykładem jest bezpieczeństwo. Mówiąc o bezpieczeństwie Związek Sowiecki, a później Rosja rozumieja równowage sił. Żeby lepiej zobrazować to odmienne rozumienie słów można przytoczyć polski wątek. Wszelkie próby instalacji tarczy antyrakietowej w Polsce i Czechach wywołały gwałtowny sprzeciw Rosji, która uznaje umieszczanie tych instalacji jako wrogie zamierzenie. Można zapytać, jak defensywne instalacje moga stanowić zagrożenie? Takie myślenie o bezpieczeństwie jest głęboko zakorzenione od czasów zimnej wojny, kiedy to gwarantem pokoju miała być równowaga sił. Każde zdobycie przewagi technologicznej przez USA (np. przez program tzw. gwiezdnych wojen) było uznawane za naruszenie równowagi, a co za tym idzie utraty bezpieczeństwa przez ZSRS. Podobny schemat działa obecnie także w przypadku tarczy antyrakietowej.

${ }^{18}$ M. Heller, Historia Imperium Rosyjskiego, Warszawa 2000, s 78. 


\section{STAŁE CZYNNIKI W ROSYJSKIEJ POLITYCE ZAGRANICZNEJ}

Alfred Rieber nie był pierwszym badaczem szukajacym stałych czynników w rosyjskiej polityce. Już w 1947 roku, próbując zrozumieć zwycięski Związek Sowiecki, amerykański badacz rosyjskiego pochodzenia Waldemar Gurian doszukiwał się stałych czynników w niezrozumiałej w oczach Zachodu polityce zagranicznej tego państwa. Pierwszą rzecza, jaką dostrzegł, było znaczenie ideologii. Gurian stwierdza, że polityka zagraniczna Rosji nie zawsze była oparta na racjonalnych przesłankach i dostrzega w niej silny ładunek ideowy, nawet utopijny ${ }^{19}$. Inny badacz, Hugh Ragsdale, kilka dekad później stwierdził, że rosyjska polityka zagraniczna zawsze oparta była na ideach (idea driven) i wspomina rosyjska „potrzebę morza”, tj. posiadanie portów na niemarznących morzach, XIX-wieczny panslawizm czy XX-wieczny komunizm. Do tego zestawienia można dodać bardziej współczesne, wielkoruskie plany odbudowy imperium przez Władimira Putina. Co jest najbardziej uderzające, to to, że większość $z$ tych przedsięwzięć, nawet próba zdobycia portów na morzu Bałtyckim, wcale nie miała i nie ma podłoża ekonomicznego. Porty na Morzu Bałtyckim miały służyć przede wszystkim celom wojskowym państwa i możliwości utrzymania floty ${ }^{20}$. Nie do przecenienia jest również rola cerkwi prawosławnej, której wpływ w zakresie idei można prześledzić od początków Księstwa Moskiewskiego po dziś dzień.

Nie jest jednak tak, że to tylko idee leżą u podstaw rosyjskiej polityki zagranicznej. Gurian wspomina również, że choć wszelkie działania wywodzą się $z$ idei, to zawsze sa one temperowane przez cyniczny realizm i odpowiednio dostosowywane w zależności od sytuacji.

Kolejnym trwałym elementem rosyjskiej polityki zagranicznej, który wymienia Gurian, jest niezwykła elastyczność w zmienianiu prowadzonej polityki. Jest to poniekad pokłosie wspomnianego powyżej innego rozumienia różnych słów i terminów przez rosyjski (lub sowiecki) establishment polityczny wynikający $z$ jego odmiennych podstaw cywilizacyjnych i co za tym idzie innej mentalności.

Zanim przejdę do analizy propozycji Riebera, warto przyjrzeć się, co sami Rosjanie uważaja za determinanty ich polityki zagranicznej. Na przykład Tatiana Graczowa uznaje prymat czynnika kulturowo-

19 W. Gurian, Permanent Features of Soviet Foreign Policy, w: Year Book of World Affairs 1947, s. 35.

${ }^{20}$ H. Ragsdale, Traditions of Imperial Russian Foreign Policy - Problems of the Present, Agenda for the Future, w: DERS. Imperial Russian Foreign Policy, New York 1993, s. 6. 
-cywilizacyjnego czyli siłę sakralno-duchową ${ }^{21}$. Jacek Bartosiak z kolei zauważa, że w większości rosyjska myśl geopolityczna podkreśla konieczność stałej ekspansji od Mikołaja Polewoja i Mikołaja Karamazina (przełom XVIII i XIX wieku) przez myśl Siergieja Uwarowa, Władimira Łamańskiego, Georgija Trubeckiego, Wadima Cymburskiego do Aleksandra Dugina - ekspansja to część rosyjskiej tradycji politycznej ${ }^{22}$. Wadim Cymburski uważał, że geograficzna izolacja Rosji wytwarza odrębność cywilizacyjna i kulturowa. Stworzył on także koncepcje „Rosji-wyspy”, kraju ograniczonego geograficznie i toczącego wojny jedynie na swoich peryferiach. To pogranicze definiowało imperium i jego politykę. Aleksander Dugin uprawia "geografię sakralną", próbując stworzyć obszar syntezy, tj. Eurazję. Ponownie to czynnik cywilizacyjny jest nadrzędny nad geograficznym.

Wyżej wymienione elementy oparte sa na analizie kultury i cywilizacji. Analiza ta nie byłaby pełna bez uwzględnienia geograficznych czy nawet geopolitycznych wpływów formujących trwałe czynniki w polityce zagranicznej Rosji. $Z$ pomoca przychodzi Alfred Rieber, który zaproponował bardziej kompleksowe badanie stałych czynników, jednocześnie tworząc usystematyzowane metody prowadzenia takich badań.

Analizując rosyjską politykę zagraniczną, wyróżnił on dwa rodzaje czynników, które na nią wpływają. Pierwszą grupę określił jako trwałe (consistant factors), druga jako czynniki zależne lub koniunkturalne (conjunctural factors) ${ }^{23}$. Wśród trwałych czynników wymienia on zapóźnienie gospodarcze, przepuszczalne granice, niespokojne pogranicze oraz kulturowa alienację. Wśród czynników zależnych wymienia jeden zewnętrzny i jeden wewnętrzny, tj. zmienny układ międzynarodowy oraz kształt elit rządzących ${ }^{24}$.

Zapóźnienie gospodarcze stanowi jeden $z$ najpoważniejszych trwałych czynników. Jednakże, żeby mówić o zapóźnieniu, należy mieć punkt odniesienia: zapóźnienie w stosunku do czego? Jedynym punktem odniesienia $\mathrm{w}$ tym wypadku jest Zachód, czyli Europa. Jeszcze w czasach średniowiecza niesprzyjajacy i ostry klimat po-

21 T.Graczowa, Święta Ruś przeciw Chazarii, Riazań 2009.

22 J. Bartosiak, Rzeczpospolita między ladem a morzem. O wojnie i pokoju Warszawa 2018, s. 334-335.

${ }^{23}$ A. Rieber, How persitent are persistent..., s. 205-209.

${ }^{24}$ Można argumentować, że na kształt elit rządzacych również mają wpływ stałe czynniki. Jednakże, w rozumieniu Riebera, chodzi np. o cechy charakteru aktualnej elity rządzacej (a więc czynniki o relatywnie dużej zmienności). 
wodował krótsze okresy wegetacyjne roślin, ograniczając potencjał rozwojowy gospodarki opartej na rolnictwie. Do tego należy dodać nieurodzajne gleby, brak dostępu do morza czy brak dostępu do kamienia potrzebnego do konstrukcji budynków. Księstwo Moskiewskie, co prawda, kontrolowało rzeki, takie jak Wołga czy Dniepr, ale nie kontrolowało już ich ujść, co blokowało rozwój handlu. Rolnicza produkcja i brak możliwości handlu powodowały poważne ograniczenia, które przezwyciężono dopiero po stuleciach ekspansji. Ekspansja była więc jedynym motorem rozwoju. Początkowo łatwa na wschodzie, na zachodzie wiazała się $z$ długotrwałymi konfliktami. W ten sposób zdobycie żyznych czarnoziemów i innych wartościowych ziem okupione było ogromnym wysiłkiem militarnym, który dotkną wszystkie klasy społeczne zmuszone do świadczenia danin wobec władzy. Jak wspomniano wcześniej, większość z nich służyła do utrzymania armii i stanowiła znaczna część wydatków państwa. Modernizacja dotyczyła przede wszystkim techniki wojskowej, a nie gospodarki. Rosji udało się zmodernizować swoje wojsko w XVII i XVIII wieku, jednak nie udało się jej przeprowadzić industrializacji. Również plan masowego uprzemysłowienia w Związku Sowieckim był uwarunkowany wysiłkiem wojennym, a później chęcią utrzymania tempa w wyścigu zbrojeń podczas zimnej wojny. Nawet dzisiaj zyski ze sprzedaży surowców służą do utrzymania i modernizacji armii, a nie jak w przypadku Norwegii programom wspierającym i zabezpieczającym dobrostan obywateli.

Drugim trwałym czynnikiem wymienionym przez Riebera sa przepuszczalne granice. Podobnie jak zapóźnienie gospodarcze czynnik ten pojawił się już w czasach Księstwa Moskiewskiego. Przepuszczalne granice stanowia poważny problem nie tylko dlatego, że pozwalaja wrogowi łatwiej zaatakować dany kraj, ale również umożliwiaja populacji na łatwe przemieszczanie się i ucieczkę. Skutkiem tego była polityka radykalnego przywiązania chłopów do swojej ziemi. Rosyjska arystokracja również była ograniczona w możliwościach podróży. Poza krótkimi reformatorskimi okresami (Piotr I, Katarzyna II, Aleksander I itd.), przez większość czasu państwo blokowało podróżnicze zapędy swoich poddanych. Car Mikołaj I przyjął drakońskie regulacje dotyczące studiowania za granicą. Co ciekawe, większość ograniczeń wiązała się z ideowymi „chorobami”, które podróżnicy mogli przywlec ze soba. Po każdej europejskiej rewolucji możliwości wyjazdu Rosjan były mocno ograniczane. Jak widać, to właśnie antyzachodni sentyment odgrywał znaczaca rolę we wprowadzaniu tych ograniczeń. Taki 
lęk przed importem idei odbijał się również na imporcie potrzebnych technologii i w ten sposób pogłębiał gospodarcze zapóźnienie.

Podobnie jak w przypadku zapóźnienia gospodarczego ZSRS próbował rozwiąać problem swoich przepuszczalnych granic. Ograniczył się od zachodu kordonem zależnych państw, a w państwach tych powstawały mury i zasieki uniemożliwiajace przepływ ludności. Podobnie jak poprzednio sowieckie remedium tylko pogłębiło i utrwaliło problem. Granice poszczególnych republik sowieckich nie były tworzone $z$ myślą, że kiedykolwiek staną się granicami zewnętrznymi państwa. Taki przypadkowy kształt rosyjskiej granicy powoduje masowy nielegalny przepływ ludności. Szczególnym problemem jest przemyt narkotyków i broni. Rosja jest również szczególnie narażona na penetrację ze strony islamskich terrorystów. Podobnie jak wcześniej przepuszczalne granice przyczyniaja się do prób kontroli przepływu ludności, a co za tym idzie tworzenia bardziej represyjnego państwa.

Przepuszczalne granice warunkuja też kolejny $z$ trwałych czynników czyli niespokojne pogranicze. Zarówno ekspansja na wschód jak i na zachód włączyła w obręb rosyjskiego imperium różne grupy etniczne i różne grupy wyznaniowe. Na wschodzie problemy sprawiali azjatyccy nomadzi. Tylko Baszkirzy w samym wieku XVIII wywołali trzy powstania przeciwko rosyjskiej dominacji. Na Zachodzie zaś Rosja musiała poradzić sobie najpierw $z$ niezależnymi kozakami, a później z Polakami, którzy niepokoili swoimi powstaniami Rosję w XIX wieku. Chcąc ograniczyć wybuchowy i niestabilny charakter swojego pogranicza, Rosja stosowała przesiedlenia całych grup ludności w głąb Syberii. Ten model został rozwinięty w Związku Sowieckim, gdzie jeszcze przed II wojna światowa represjonowano i przesiedlano grupy ludności $z$ pogranicza, które zostały uznane za niosace zagrożenie. Represje te dotknęły Polaków, Niemców, Japończyków czy Koreańczyków. Po wojnie zaś represje objęły muzułmańskie społeczności Tatarów, Czeczenów czy Kałmuków. Podobną zasadę oczyszczania terenów granicznych stosowano w podbitych państwach Środkowej Europy (vide akcja „Wisła”).

Wraz $z$ rozpadem Zwiazku Sowieckiego problem pogranicza uległ intensyfikacji, tworząc liczne punkty zapalne. Upadek sowieckiego imperium pozostawił również liczne grupy Rosjan poza granicami obecnego państwa oraz pozostawił liczne mniejszości w terenach przygranicznych. Dwie wojny prowadzone w Czeczenii czy niedawne zajęcie Krymu i hybrydowa wojna prowadzona na wschodzie Ukra- 
iny $\mathrm{w}$ smutny sposób potwierdza stałość problemu niespokojnego pogranicza.

Kwestia ostatniego stałego czynnika wymienionego przez Riebera, czyli kulturowej alienacji została już omówiona wcześniej podczas przedstawiania cywilizacyjnych podstaw odmienności Rosji wobec Zachodu. Jako najnowszy jej przejaw można wymienić ideę eurazjatyzmu, której najbardziej znanym przedstawicielem jest Aleksander Dugin. Wpływ idei głoszonych przez Dugina na prezydenta Władimira Putina jest powszechnie znany. Głównym założeniem eurazjatyzmu jest przekonanie o kulturowej i cywilizacyjnej odmienności Rosji od Europy. Jednocześnie Rosję przeciwstawia Zachodowi. Ten antagonizm, jak wykazano powyżej, posiada długie tradycje i stanowi trwały czynnik kształtujaccy rosyjska mentalność i rosyjska politykę.

\section{PODSUMOWANIE}

W 1839 roku Rosję odwiedził francuski arystokrata markiz Astolphe de Custine. W czasie podróży Francuz notował swoje przemyślenia. Jego Listy $z$ Rosji stanowia interesujacy wgląd w XIX-wieczna Rosję. Co ciekawe, amerykański ambasador w ZSRS George Kennan, miał o książce francuskiego arystokraty powiedzieć: „Nawet jeśli przyjmiemy, że ksiażka de Custine'a nie była dobra ksiażka o Rosji w roku 1839, pozostaje niepokojący fakt, że była książką znakomita, chyba najlepsza ze wszystkich, jakie napisano o Rosji Stalina, a także książką zupełnie niezłą o Rosji Breżniewa"25. Dziś zapewne dodałby, że jest również całkiem przyzwoitym tekstem o Rosji Putina. Przytoczone powyżej przykłady świadczą o tym, że nawet przy pozornie zerwanej ciagłości przez rewolucję październikowa w przypadku Rosji ciagle można dyskutować o długotrwałych czynnikach. Większość współczesnych problemów tego kraju w polityce zagranicznej wywodzi się nie tyle $z$ czasów sowieckich, ale jest pokłosiem wspomnianych powyżej trwałych elementów, które tę politykę zagraniczna warunkują. Kolejne kryzysy międzynarodowe związane $z$ Rosją tylko uwypuklają obecność trwałych czynników.

Jak widać na rosyjskim przykładzie przyjęcie i zastosowanie perspektywy badawczej w postaci trwałych czynników może dać ciekawe efekty poznawcze. Perspektywa ta przełamuje ograniczenia wynikające $z$ paradygmatu geopolitycznego, choć twórczo go wykorzystuje.

${ }^{25}$ Cyt za: R. Krawczyk, Podstawy cywilizacji..., s. 323. 
Jednocześnie inkorporacja elementów cywilizacyjnych i kulturowych $\mathrm{w}$ perspektywie długiego trwania pozwala namalować dokładniejszy obraz czynników warunkujących politykę zagraniczną danego państwa.

Zaproponowana przez Alfreda Riebera perspektywa otwiera nowe pola badawcze. Szczególnie ciekawe moga być rezultaty jej zastosowania wobec państw, które przechodziły radykalne zmiany swoich granic i form ustrojowych, takich jak Niemcy czy Polska. Mam nadzieję, że poniższy artykuł stanowi zachętę do podjęcia tego rodzaju naukowych dociekań. 